\title{
Association between short-term exposure to air pollution and COVID-19 hospital admission/mortality during warm seasons
}

\author{
Babak Khorsandi (D) Kiarash Farzad • \\ Hannaneh Tahriri $\cdot$ Reza Maknoon
}

Received: 8 April 2021 / Accepted: 12 June 2021 / Published online: 18 June 2021

(C) The Author(s), under exclusive licence to Springer Nature Switzerland AG 2021

\begin{abstract}
COVID-19 is a new viral infection that is usually accompanied by respiratory complications. Air pollution has been linked to cardiorespiratoryrelated diseases and even premature mortality. The short-term exposure to air pollution may aggravate pulmonary symptoms in COVID-19 patients. The relationship between the short-term exposure to air pollution and hospital admission and mortality resulting from COVID-19 will be examined in Tehran, Iran, during the spring and summer of 2020. The statistics of $\mathrm{PM}_{2.5}, \mathrm{PM}_{10}$, and 8-h maximum ozone $\left(\mathrm{O}_{3}\right)$ concentrations, meteorological conditions, and COVID-19 hospital admissions/mortality were analyzed. The cross-correlation and temporal relationship between the daily concentration of the aforementioned pollutants (as well as the meteorological conditions) and the COVID-19 hospital admissions/ mortality rate was calculated for each month. The concentration of $\mathrm{PM}_{2.5}, \mathrm{PM}_{10}$, and 8-h maximum $\mathrm{O}_{3}$, along with temperature, increased in the summer. The hospital admissions and mortality associated with COVID-19 decreased from the first peak in the spring and then increased to its second peak in the summer. The short-term exposure to ambient $\mathrm{PM}_{2.5}, \mathrm{PM}_{10}, \mathrm{O}_{3}$, and elevated temperatures is associated with higher
\end{abstract}

B. Khorsandi $(\bowtie) \cdot$ K. Farzad $\cdot$ H. Tahriri $\cdot$ R. Maknoon Department of Civil and Environmental Engineering, Amirkabir University of Technology (Tehran Polytechnic), 350 Hafez Street, 15916-34311 Tehran, Iran e-mail: b.khorsandi@aut.ac.ir rates of COVID-19-related hospital admissions/mortality throughout the summer. Among these variables, the correlation with $\mathrm{O}_{3}$ was statistically significant in more summer months. The short-term exposure to air pollution (especially $\mathrm{O}_{3}$ ) may increase the susceptibility of the population infected with COVID-19 and, therefore, increases the rate of hospital admissions and mortality even during the warm seasons.

Keywords COVID-19 - Air pollution · Ozone · Short-term exposure $\cdot$ Tehran

\section{Introduction}

The outbreak of the novel coronavirus disease 2019 (COVID-19), which was first emerged in Wuhan, China, in December 2019, soon became a pandemic. The different rates of infection and mortality due to COVID-19 in various regions of the world may be attributed to air quality and meteorological conditions (temperature and relative humidity) as well as demographic characteristics (e.g., age, gender, race, ethnicity, and income). Air pollution has numerous adverse impacts on human health and can lead to premature mortality (Ahmadi et al., 2020; Bell et al., 2004; Farzad et al., 2020, 2021; Hoek et al., 2013; Janssen et al., 2012; Krewski et al., 2009; Mirzaei et al., 2021). The potential association between different pollutants (specifically $\mathrm{PM}_{2.5}$ ) and COVID-19 mortality has been recently examined mainly in China, Italy, and the USA (Bashir et al., 2020; Coker et al., 2020; Contini 
\& Costabile, 2020; Copat et al., 2020; Deek, 2020; Domingo \& Rovira, 2020; Fattorini \& Regoli, 2020; Frontera et al., 2020; Hendryx \& Luo, 2020; Jiang \& Xu, 2020; Stieb et al., 2020; Wu et al., 2020; Yao et al., 2020a, b; Zoran 2020a, b). It has been hypothesized that exposure to air pollution can impair the cardiorespiratory system and increase the population's susceptibility to COVID19 infection, therefore, accelerating the rate of mortality (Contini \& Costabile, 2020; Fattorini \& Regoli, 2020; Hendryx \& Luo, 2020). Although no evidence has been found on the airborne transmission of the novel coronavirus by particulate matter in the outdoor environment (Bontempi, 2020), however, such a mechanism may not be ruled out in indoor environments, e.g., hospitals (Santarpia et al., 2020).

COVID-19 was first reported in Iran in late February 2020, almost 3 months after its emergence in China. Since then, the number of newly infected cases and deaths due to COVID-19 has been relatively high in Iran. Tehran, the capital of the country and its most populated metropolitan area, has been worst affected by the outbreak in Iran. Tehran's ambient air is also one of the most polluted in the Middle East. In this study, we aim to examine the temporal cross-correlation between daily exposure to air pollutants $\left(\mathrm{PM}_{2.5}\right.$, $\mathrm{PM}_{10}$, and ground-level ozone $\left(\mathrm{O}_{3}\right)$ ), as well as meteorological conditions, and hospital admission/mortality rate associated with COVID-19 in Tehran during the spring and summer 2020. To our knowledge, this is the first study to analyze such a relationship in a Middle-Eastern city.

\section{Materials and methods}

Data

Tehran, one of the largest cities in the world, has a population of 8.68 million. The data for air quality, meteorological conditions (i.e., temperature and relative humidity), and COVID-19 hospital admission/ mortality for Tehran were acquired on a daily basis for spring (March, April, and May) and summer (June, July, August) 2020. Twenty-two monitoring stations operating under Air Quality Control Company (AQCC) measure the air quality at various locations in Tehran. Daily concentrations of $\mathrm{PM}_{2.5}, \mathrm{PM}_{10}$, and (8-h maximum) $\mathrm{O}_{3}$ and the Air Quality Index (AQI, which is similar to that defined by the EPA) were obtained from the AQCC. Among the criteria air pollutants, PM and $\mathrm{O}_{3}$ were selected because they are predominant (their concentrations usually exceed the standards) in Tehran throughout the year and warm seasons, respectively. The temperature and relative humidity data of Tehran (measured at the Mehrabad meteorological monitoring station) were retrieved from the Iowa State University database ("ASOS-AWOS-METAR Data Download," 2020). The daily number of hospital admissions and mortality due to COVID-19 were acquired from Tehran's Coronavirus Combat Taskforce and the Shahid Beheshti University of Medical Sciences. It is worth noting that the hospital admissions were also included in the analysis as it implies severe symptoms for which the patients require further observation and treatment.

\section{Statistics}

The statistics pertaining to $\mathrm{PM}_{2.5}, \mathrm{PM}_{10}$, and (8-h maximum) $\mathrm{O}_{3}$ concentrations, AQI, temperature, relative humidity, and hospital admission and mortality due to COVID-19 will be presented for each month and for the whole study period (1 March 2020 to 31 August 2020). The statistics (including the mean and standard deviation) were calculated from the daily data of the entire city (obtained by averaging the daily data across all monitoring stations).

Cross-correlation between air pollutant concentrations and hospital admission/mortality

The temporal cross-correlation was calculated between the daily exposures to air pollutants/meteorological conditions and daily hospital admission/ mortality associated with COVID-19 for the spring and summer of 2020. As the hospital admission/mortality data acquired were for the whole city, the analysis was conducted for the entire study area (rather than the individual districts). The cross-correlations were computed between air pollutant concentrations/ meteorological conditions on one day and the number of COVID-19 hospital admissions/mortalities on the same day and up to 7 days later. The maximum monthly cross-correlation and its corresponding lag interval will be presented in the results and discussion. The lag interval ( $0-7$ days) denotes the time period between exposure and hospital admission/mortality. 


\section{Results and discussion}

A summary of the statistics of air pollutant concentrations, AQI, meteorological conditions, and hospital admission and mortality due to COVID-19, during the spring and summer of 2020, are presented in Table 1. The mean (95\% confidence interval) and coefficient of variation $(\mathrm{CV}$, defined as the ratio of standard deviation to mean) were calculated from the daily data. It can be seen that the hospital admission and mortality decreased from the first peak from March to May, then increased to reach its second peak in July, and subsequently decreased again in August. The $\mathrm{CV}$ of hospital admission and mortality was drastically higher in August than those of the other months, meaning that fluctuations (relative to the mean) were much larger in that month. The concentration of pollutants, AQI, and temperature increased during the summer, while the relative humidity decreased. The significant increase in $\mathrm{O}_{3}$ concentration in the summer is due to the rise in temperature in this period. Note that the temperature rise results in accelerating the photochemical reactions and the emission of volatile organic compounds (VOCs), which in turn increases the rate of production of $\mathrm{O}_{3}$ (Coates et al., 2016). Furthermore, the analysis of the data showed that the daily concentration of $\mathrm{PM}_{2.5}, \mathrm{PM}_{10}$, and 8-h maximum $\mathrm{O}_{3}$ exceeded the WHO daily guidelines in many days during the study period. Therefore, it is expected that the short-term effect of air pollutants on the health of the population would be significant.

The cross-correlation between daily exposure to air pollution and hospital admission/mortality due to COVID-19 and the corresponding lag period (0-7 days) was examined in Tehran during the spring and summer of 2020. The results for hospital admissions and mortality are presented in Tables 2 and 3, respectively. There was no significant correlation between the exposure to air pollution and COVID-related hospital admission/ mortality in the months of spring (when the pollutant concentrations are relatively lower than those of summer months). On the other hand, the correlations between exposure to $\mathrm{O}_{3}$ and COVID-related hospital admission/mortality are positive and statistically significant $(\mathrm{p} \leq 0.01-0.1)$ throughout the summer. There is a 2-5 day lag between $\mathrm{O}_{3}$ exposure and mortality in

Table 1 A summary of statistics including mean (95\% confidence interval) and coefficient of variation (CV) of air pollutants and COVID-19 admission/mortality (calculated from the daily data) of Tehran in 2020

\begin{tabular}{|c|c|c|c|c|c|c|c|c|c|}
\hline Month & Parameter & Admission & Death & $\begin{array}{l}\mathrm{O}_{3} \\
(\mathrm{ppb})\end{array}$ & $\begin{array}{l}\mathrm{PM}_{2.5} \\
\left(\mu \mathrm{g} / \mathrm{m}^{3}\right)\end{array}$ & $\begin{array}{l}\mathrm{PM}_{10} \\
\left(\mu \mathrm{g} / \mathrm{m}^{3}\right)\end{array}$ & AQI & $\begin{array}{l}\text { Temperature } \\
\left({ }^{\circ} \mathrm{C}\right)\end{array}$ & $\begin{array}{l}\text { Relative } \\
\text { humidity (\%) }\end{array}$ \\
\hline \multirow[t]{2}{*}{ March } & Mean & $\begin{array}{l}479(445, \\
512)\end{array}$ & $63(59,68)$ & $36(33,38)$ & $22(17,26)$ & $51(42,60)$ & $69(61,76)$ & $13(12,14)$ & $41(35,47)$ \\
\hline & $\mathrm{CV}$ & 0.20 & 0.22 & 0.20 & 0.64 & 0.51 & 0.32 & 0.24 & 0.40 \\
\hline \multirow[t]{2}{*}{ April } & Mean & $\begin{array}{c}419(384, \\
455)\end{array}$ & $34(30,37)$ & $36(32,40)$ & $19(17,20)$ & $45(39,50)$ & $63(59,68)$ & $15(14,17)$ & $48(42,55)$ \\
\hline & $\mathrm{CV}$ & 0.23 & 0.31 & 0.30 & 0.24 & 0.36 & 0.20 & 0.29 & 0.37 \\
\hline \multirow[t]{2}{*}{ May } & Mean & $\begin{array}{c}283(262 \\
304)\end{array}$ & $16(14,17)$ & $48(44,53)$ & $23(20,26)$ & $65(57,74)$ & $77(69,85)$ & $24(23,26)$ & $26(22,30)$ \\
\hline & $\mathrm{CV}$ & 0.21 & 0.28 & 0.27 & 0.35 & 0.37 & 0.30 & 0.20 & 0.43 \\
\hline \multirow[t]{2}{*}{ June } & Mean & $\begin{array}{c}334(300, \\
368)\end{array}$ & $21(19,24)$ & $62(58,66)$ & $26(24,28)$ & $75(69,80)$ & $92(85,99)$ & $30(29,30)$ & $18(15,20)$ \\
\hline & $\mathrm{CV}$ & 0.29 & 0.35 & 0.18 & 0.19 & 0.20 & 0.22 & 0.08 & 0.41 \\
\hline \multirow[t]{2}{*}{ July } & Mean & $\begin{array}{c}523(479, \\
567)\end{array}$ & $34(31,36)$ & $72(68,75)$ & $27(25,29)$ & $72(66,79)$ & $\begin{array}{c}112(104, \\
120)\end{array}$ & $31(30,32)$ & $21(19,24)$ \\
\hline & $\mathrm{CV}$ & 0.24 & 0.24 & 0.14 & 0.16 & 0.25 & 0.21 & 0.07 & 0.27 \\
\hline \multirow[t]{2}{*}{ August } & Mean & $\begin{array}{c}394(329, \\
458)\end{array}$ & $14(11,18)$ & $64(60,68)$ & $24(23,26)$ & $78(72,85)$ & $90(84,96)$ & $29(28,30)$ & $27(24,29)$ \\
\hline & $\mathrm{CV}$ & 0.46 & 0.69 & 0.16 & 0.14 & 0.22 & 0.18 & 0.10 & 0.26 \\
\hline \multirow[t]{2}{*}{ Total } & Mean & $\begin{array}{c}406(384, \\
427)\end{array}$ & $31(28,33)$ & $53(50,55)$ & $23(22,24)$ & $64(61,68)$ & $84(80,87)$ & $24(23,25)$ & $30(28,32)$ \\
\hline & $\mathrm{CV}$ & 0.36 & 0.64 & 0.33 & 0.29 & 0.35 & 0.31 & 0.33 & 0.53 \\
\hline
\end{tabular}


Table 2 The highest monthly cross-correlation between air pollution/ meteorological conditions exposure and COVID19 hospital admission (R-value) and its corresponding lag period and standard error (SE)

R-values with no superscript mean $p>0.1$

${ }^{\mathrm{a}} p<0.01$

${ }^{\mathrm{b}} p<0.05$

${ }^{\mathrm{c}} p<0.1$

\begin{tabular}{|c|c|c|c|c|c|c|c|}
\hline Month & Parameter & $\mathrm{O}_{3}$ & $\mathrm{PM}_{2.5}$ & $\mathrm{PM}_{10}$ & AQI & Temperature & $\begin{array}{l}\text { Relative } \\
\text { humidity }\end{array}$ \\
\hline \multirow[t]{3}{*}{ March } & R-Value & 0.266 & 0.119 & 0.139 & 0.110 & $0.390^{\mathrm{b}}$ & 0.111 \\
\hline & Lag (day) & 3 & 3 & 3 & 2 & 3 & 5 \\
\hline & SE & 0.189 & 0.189 & 0.189 & 0.186 & 0.189 & 0.196 \\
\hline \multirow[t]{3}{*}{ April } & R-Value & - & - & - & - & - & 0.241 \\
\hline & Lag & - & - & - & - & - & 4 \\
\hline & SE & - & - & - & - & - & 0.196 \\
\hline \multirow[t]{3}{*}{ May } & R-Value & - & 0.100 & 0.276 & 0.003 & - & 0.265 \\
\hline & Lag & - & 0 & 0 & 0 & - & 0 \\
\hline & SE & - & 0.180 & 0.180 & 0.180 & - & 0.180 \\
\hline \multirow[t]{3}{*}{ June } & R-Value & $0.397^{\mathrm{b}}$ & $0.545^{\mathrm{a}}$ & $0.581^{\mathrm{a}}$ & $0.517^{\mathrm{a}}$ & 0.221 & $0.603^{\mathrm{a}}$ \\
\hline & Lag & 0 & 0 & 1 & 3 & 4 & 0 \\
\hline & $\mathrm{SE}$ & 0.183 & 0.183 & 0.186 & 0.192 & 0.196 & 0.183 \\
\hline \multirow[t]{3}{*}{ July } & R-Value & $0.356^{\mathrm{c}}$ & - & - & 0.354 & $0.493^{b}$ & 0.100 \\
\hline & Lag & 4 & - & - & 3 & 0 & 2 \\
\hline & SE & 0.192 & - & - & 0.189 & 0.180 & 0.186 \\
\hline \multirow[t]{3}{*}{ August } & R-Value & $0.537^{\mathrm{a}}$ & 0.235 & 0.271 & 0.480 & $0.471^{\mathrm{b}}$ & 0.235 \\
\hline & Lag & 2 & 0 & 0 & 1 & 3 & 0 \\
\hline & $\mathrm{SE}$ & 0.189 & 0.183 & 0.183 & 0.186 & 0.192 & 0.183 \\
\hline
\end{tabular}

this period. The correlation is statistically significant $(\mathrm{p} \leq 0.05)$ between $\mathrm{PM}_{2.5}$ and $\mathrm{PM}_{10}$ and COVID-related hospital admission/mortality only in June. In this month, the lag period between $\mathrm{PM}_{2.5}$ and $\mathrm{PM}_{10}$ and mortality is 4 and 2 days, respectively. It is worth noting that as $\mathrm{PM}_{2.5}$ and $\mathrm{PM}_{10}$ are highly correlated, similar trends are
Table 3 The highest monthly cross-correlation between air pollution/ meteorological conditions exposure and COVID-19 mortality (R-value) and its corresponding lag period (in days) and standard error (SE)

R-values with no superscript mean $\mathrm{p}>0.1$

${ }^{\mathrm{a}} p<0.01$

${ }^{\mathrm{b}} p<0.05$

${ }^{\mathrm{c}} p<0.1$

\begin{tabular}{|c|c|c|c|c|c|c|c|}
\hline Month & Parameter & $\mathrm{O}_{3}$ & $\mathrm{PM}_{2.5}$ & $\mathrm{PM}_{10}$ & AQI & Temperature & $\begin{array}{l}\text { Relative } \\
\text { humidity }\end{array}$ \\
\hline \multirow[t]{3}{*}{ March } & R-Value & 0.215 & 0.170 & 0.139 & 0.166 & 0.256 & 0.162 \\
\hline & Lag & 3 & 5 & 5 & 5 & 3 & 5 \\
\hline & SE & 0.189 & 0.196 & 0.196 & 0.196 & 0.189 & 0.196 \\
\hline \multirow[t]{3}{*}{ April } & R-Value & - & - & - & - & - & 0.241 \\
\hline & Lag & - & - & - & - & - & 4 \\
\hline & SE & - & - & - & - & - & 0.196 \\
\hline \multirow[t]{3}{*}{ May } & R-Value & - & - & 0.024 & 0.024 & - & 0.271 \\
\hline & Lag & - & - & 2 & 2 & - & 4 \\
\hline & SE & - & - & 0.186 & 0.186 & - & 0.192 \\
\hline \multirow[t]{3}{*}{ June } & R-Value & $0.376^{\mathrm{c}}$ & $0.491^{\mathrm{b}}$ & $0.392^{\mathrm{b}}$ & $0.451^{\mathrm{b}}$ & 0.184 & 0.250 \\
\hline & Lag & 5 & 4 & 2 & 4 & 3 & 2 \\
\hline & SE & 0.192 & 0.196 & 0.189 & 0.196 & 0.192 & 0.189 \\
\hline \multirow[t]{3}{*}{ July } & R-Value & $0.383^{\mathrm{c}}$ & - & - & 0.302 & $0.412^{\mathrm{b}}$ & - \\
\hline & Lag & 4 & - & - & 3 & 0 & - \\
\hline & $\mathrm{SE}$ & 0.196 & - & - & 0.189 & 0.180 & - \\
\hline \multirow[t]{3}{*}{ August } & R-Value & 0.289 & 0.158 & - & 0.219 & $0.420^{\mathrm{b}}$ & 0.183 \\
\hline & Lag & 2 & 1 & - & 2 & 0 & 0 \\
\hline & SE & 0.186 & 0.186 & - & 0.189 & 0.183 & 0.183 \\
\hline
\end{tabular}


observed for these pollutants. The correlations between AQI and COVID-related hospital admission/mortality are approximately similar to those of $\mathrm{PM}_{2.5}$ and $\mathrm{PM}_{10}$ from March to June, when these pollutants are dominant, and to that of $\mathrm{O}_{3}$ from July to August when the concentration of this pollutant reaches its highest values in the course of the study period. Furthermore, there appears to be a direct and statistically significant correlation between temperature and COVID-related hospital admission/mortality $(\mathrm{p} \leq 0.05)$ in July and August. The lag period is $0-4$ days between temperature exposure and hospital admission/mortality. The results also show a positive correlation between the relative humidity and COVID-19 hospital admission/mortality; however, the relationship was found to be statistically significant only for COVID-19 hospital admission in June.

\section{Conclusions}

The short-term exposure to $\mathrm{PM}_{2.5}, \mathrm{PM}_{10}$, and $\mathrm{O}_{3}$ and elevated temperatures is significantly associated with COVID-19-related hospital admission and mortality during the summer in Tehran. Our findings, within the limitations of an observational study, confirm the hypothesis claimed by other studies that air pollution increases the vulnerability of the population resulting in higher rates of mortality due to COVID-19 infection. For future studies, it would be beneficial to further examine the relationship between air pollution and COVID-19 cases during the fall and winter of 2020, when the concentrations of air pollutants (except $\mathrm{O}_{3}$ ) will significantly increase in Tehran.

\section{Limitations}

The current study was limited by its retrospective and observational nature. There is inherent heterogeneity in the cohort in terms of age, gender, geographic location, socio-economic background, and preexisting comorbidities that might have affected the outcomes.

Acknowledgements The authors would like to thank Tehran's Coronavirus Combat Taskforce and the Shahid Beheshti University of Medical Sciences, especially Prof. Alireza Zali and Prof. Ali Maher, for providing COVID-19 hospital admission and mortality data and permission for their publication.
Author contribution Babak Khorsandi, $\mathrm{PhD}$ (co-supervisor): supervision, conceptualization, methodology, investigation, resources, validation, writing-original draft, writing-review and editing, project administration. Kiarash Farzad (graduate student): conceptualization, methodology, software, investigation, resources, data curation. Hannaneh Tahriri (graduate student): methodology, software, investigation, data curation. Reza Maknoon, $\mathrm{PhD}$ (co-supervisor): supervision, validation

Availability of data and material The air pollution and meteorological data that support the findings of this study are available from the corresponding author upon reasonable request. The COVID-19 data would only be available upon the approval of Tehran's Coronavirus Combat Taskforce.

\section{Declarations}

Conflict of interest The authors declare no competing interests.

\section{References}

Ahmadi, M., Khorsandi, B., \& Mesbah, M. (2020). The effect of air pollution on drivers' safety performance. Environmental Science and Pollution Research, 28, 15768-15781. https://doi.org/10.1007/s11356-020-11687-y.

ASOS-AWOS-METAR Data Download [WWW Document]. (2020). Iowa State Univ. https://mesonet.agron.iastate. edu/request/download.phtml. Accessed 25 Sept 2020.

Bashir, M. F., Bilal, B. M., \& Komal, B. (2020). Correlation between environmental pollution indicators and COVID-19 pandemic: A brief study in Californian context. Environmental Research, 187, 109652. https://doi.org/10.1016/j. envres.2020.109652

Bell, M. L., McDermott, A., Zeger, S. L., Samet, J. M., \& Dominici, F. (2004). Ozone and short-term mortality in 95 US urban communities, 1987-2000. JAMA, 292, 23722378. https://doi.org/10.1001/jama.292.19.2372

Bontempi, E. (2020). First data analysis about possible COVID-19 virus airborne diffusion due to air particulate matter (PM): The case of Lombardy (Italy). Environmental Research, 186, 109639. https://doi.org/10.1016/j. envres.2020.109639

Coates, J., Mar, K. A., Ojha, N., \& Butler, T. M. (2016). The influence of temperature on ozone production under varying NOx conditions - a modelling study. Atmospheric Chemistry and Physics, 16, 11601-11615. https://doi.org/ 10.5194/acp-16-11601-2016

Coker, E. S., Cavalli, L., Fabrizi, E., Guastella, G., Lippo, E., Parisi, M. L., Pontarollo, N., Rizzati, M., Varacca, A., \& Vergalli, S. (2020). The effects of air pollution on COVID-19 related mortality in northern Italy. Environmental and Resource Economics, 76, 611-634. https://doi. org/10.1007/s10640-020-00486-1

Copat, C., Cristaldi, A., Fiore, M., Grasso, A., Zuccarello, P., Santo, S. S., Conti, G. O., \& Ferrante, M. (2020). The role of air pollution (PM and NO2) in COVID-19 spread and 
lethality: A systematic review. Environmental Research, 191, 110129. https://doi.org/10.1016/j.envres.2020.110129

Contini, D., \& Costabile, F. (2020). Does air pollution influence COVID-19 outbreaks? Atmosphere, 11, 377. https:// doi.org/10.3390/atmos 11040377

Deek, S. A. (2020). Chronic exposure to air pollution implications on COVID-19 severity. Medical Hypotheses, 145, 110303. https://doi.org/10.1016/j.mehy.2020.110303

Domingo, J. L., \& Rovira, J. (2020). Effects of air pollutants on the transmission and severity of respiratory viral infections. Environmental Research, 187, 109650. https://doi. org/10.1016/j.envres.2020.109650

Farzad, K., Khorsandi, B., Khorsandi, M., Bouamra, O., \& Maknoon, R. (2021). Estimating short-term mortality benefits associated with a reduction in tropospheric ozone. Atmospheric Environment, 252, 118342. https://doi.org/ 10.1016/j.atmosenv.2021.118342

Farzad, K., Khorsandi, B., Khorsandi, M., Bouamra, O., \& Maknoon, R. (2020). A study of cardiorespiratory related mortality as a result of exposure to black carbon. Science of the Total Environment, 725, 138422. https://doi.org/10. 1016/j.scitotenv.2020.138422

Fattorini, D., \& Regoli, F. (2020). Role of the chronic air pollution levels in the Covid-19 outbreak risk in Italy. Environmental Pollution, 264, 114732.https://doi.org/10.1016/j. envpol.2020.114732

Frontera, A., Cianfanelli, L., Vlachos, K., Landoni, G., \& Cremona, G. (2020). Severe air pollution links to higher mortality in COVID-19 patients: The "double-hit" hypothesis. Journal of Infection, 81, 255-259. https://doi.org/10.1016/j.jinf.2020.05. 031

Hendryx, M., \& Luo, J. (2020). COVID-19 prevalence and fatality rates in association with air pollution emission concentrations and emission sources. Environmental Pollution, 265, 115126. https://doi.org/10.1016/j.envpol. 2020.115126

Hoek, G., Krishnan, R. M., Beelen, R., Annette, P., Ostro, B., Brunekreef, B., \& Kaufman, J. (2013). Long-term air pollution exposure and cardio- respiratory mortality: A review. Environmental Health, 12, 43. https://doi.org/10. 1186/1476-069X-12-43

Janssen, N.A.H., Gerlofs-Nijland, M.E., Lanki, T., Salonen, R.O., Cassee, F., Hoek, G., Fischer, P., Brunekreef, B., Krzyzanowski, M. (2012). Health effects of black carbon, World Health Organization.

Jiang Y., Xu J. (2020). The association between COVID-19 deaths and short-term ambient air pollution/meteorological condition exposure: A retrospective study from Wuhan, China. Air Quality, Atmosphere and Health. https://doi.org/10.1007/s11869-020-00906-7
Krewski, D., Jerrett, M., Burnett, R. T., Ma, R., Hughes, E., Shi, Y., \& Tempalski, B. (2009). Extended follow-up and spatial analysis of the American Cancer Society study linking particulate air pollution and mortality (pp. 5-114). Boston, MA: Health Effects Institute.

Mirzaei, A., Tahriri, H., \& Khorsandi, B. (2021). Comparison between AirQ+ and BenMAP-CE in estimating the health benefits of PM 2.5 reduction. Air Quality, Atmosphere \& Health, 14, 807-815. https://doi.org/10.1007/ s11869-021-00980-5

Santarpia, J. L., Rivera, D. N., Herrera, V., Morwitzer, M. J., Creager, H., Santarpia, G. W., \& Lowe, J. J. (2020). Aerosol and surface transmission potential of SARS-CoV-2. MedRxiv. https://doi. org/10.1101/2020.03.23.20039446

Stieb, D. M., Evans, G. J., To, T. M., Brook, J. R., \& Burnett, R. T. (2020). An ecological analysis of long-term exposure to PM2. 5 and incidence of COVID-19 in Canadian health regions. Environmental Research, 191, 110052. https://doi.org/10.1016/j.envres.2020.110052

Wu, X., Nethery, R.C., Sabath, M.B., Braun, D., \& Dominici, F. (2020). Air pollution and COVID-19 mortality in the United States: Strengths and limitations of an ecological regression analysis. Science Advances, 6, 45: eabd4049. https://doi.org/10.1126/sciadv.abd4049

Yao, Y., Pan, J., Liu, Z., Meng, X., Wang, W., Kan, H., \& Wang, W. (2020a). Temporal association between particulate matter pollution and case fatality rate of COVID-19 in Wuhan. Environmental Research, 189, 109941. https:// doi.org/10.1016/j.envres.2020.109941

Yao, Y., Pan, J., Wang, W., Liu, Z., Kan, H., Qiu, Y., Meng, X., \& Wang, W. (2020b). Association of particulate matter pollution and case fatality rate of COVID-19 in 49 Chinese cities. Science of the Total Environment, 741, 140396. https://doi.org/10.1016/j.scitotenv.2020.140396

Zoran, M. A., Savastru, R. S., Savastru, D. M., \& Tautan, M. N. (2020a). Assessing the relationship between ground levels of ozone (O3) and nitrogen dioxide (NO2) with coronavirus (COVID-19) in Milan, Italy. Science of The Total Environment, 740, 140005.

Zoran M. A., Savastru R. S., Savastru D. M., Tautan M. N. (2020b). Assessing the relationship between surface levels of PM2.5 and PM10 particulate matter impact on COVID19 in Milan, Italy. Science of the Total Environment, 738, 139825. https://doi.org/10.1016/j.scitotenv.2020.139825

Publisher's Note Springer Nature remains neutral with regard to jurisdictional claims in published maps and institutional affiliations. 